\title{
Graduate Student Literature Review: Understanding the genetic mechanisms underlying mastitis*
}

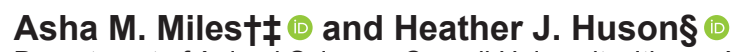

Department of Animal Science, Cornell University, Ithaca, NY 14853

\begin{abstract}
Mastitis is the costliest disease facing dairy producers today; consequently, it has been the subject of substantial research focus. Efforts have evolved from an initial focus on understanding the etiology of intramammary infections to the application of preventative measures, including attempts to breed cows that are resistant to infection. However, breeding for resistance to infection has proven difficult, given the complexity of the disease and the high expense associated with assembling highquality genotypes and phenotypes. This review provides a brief background on mastitis; illustrates current understanding of the genetics influencing mastitis and the application of this knowledge; and discusses challenges and limitations in understanding these mechanisms and applying these findings to genetic improvement strategies.
\end{abstract}

Key words: mastitis, genetics, genetic selection, complex traits

\section{INTRODUCTION}

Mastitis prevention and control preoccupies producers, veterinarians, and researchers alike; as a result, our understanding of mastitis has increased exponentially over recent decades. Areas of focus range from adjusting milking practices to improving milking machine design and function, and from monitoring cow hygiene to implementing dry-cow treatment protocols. Among the many mastitis mitigation strategies is the breeding objective of selecting for cows that display natural mastitis resistance. Substantial progress has been made

Received January 31, 2020.

Accepted August 16, 2020.

* Submitted to the 2021 ADSA Foundation Graduate Student Literature Review Competition (Production, PhD) on August 26, 2020.

†Corresponding author: amm486@cornell.edu

$\ddagger$ Current address: Department of Animal Science, The Pennsylvania State University, University Park, PA 16802.

§Advisor (hjh3@cornell.edu). in this area thanks to the efforts of national genetic evaluation systems, but understanding the genetic mechanisms underlying mastitis has proven difficult because of the complex nature of the trait itself, as well as the overwhelming environmental effect on mastitis propagation. The purpose of this review is to provide a brief background on mastitis; illustrate current understanding of the genetics influencing mastitis and the application of this knowledge; and discuss challenges and limitations in understanding these mechanisms and applying these findings to genetic improvement strategies.

\section{ORIGINS}

The term "mastitis" originates from the Greek mastos, meaning "breast," and -itis, a suffix meaning "inflammation." Inflammation etymology can be traced to the Latin inflammationem, which may be translated as "a kindling, a setting on fire," and indeed, inflammation can be clinically described as heat, pain, redness, and swelling - symptoms that reflect the influence of inflammatory mediators on infected tissue. Heat, redness, and swelling are accounted for by the increased permeability of blood vessels and subsequent leakage of fluid and proteins; and pain explained by the migration and action of immune response cells. We define these effects as "clinical mastitis," which produces visible abnormalities in the milk and in the mammary gland. Mastitis can also present subclinically, in which inflammatory effects are detectable only with diagnostic tests for microorganisms, the influx of inflammatory response cells (somatic cells) in the milk, or both. This host response to threats to biological homeostasis is a protective function intended to destroy the pathogen and return the mammary gland to normal function. This innate immune response predates metazoans, and adaptive immunity first appeared in jawed fish before the evolution of mammals; it is therefore likely that mastitis has been a prevalent issue since mammals first appeared in the late Triassic period, an estimated 200 million years ago (Novacek, 1997; Flajnik and Kasahara, 2010; Muthamilarasan and Prasad, 2013). 
Archeozoological studies exploring mitochondrial DNA variation suggest that cattle were first domesticated approximately 10,500 years ago, and historical evidence suggests that humans began milking cows approximately 3,000 years after that (Itan et al., 2009; Bollongino et al., 2012). We know today that mastitis is propagated by both environmental and contagious pathogens, the latter of which are often spread during milking. It is likely that concerns about the management and control of mastitis began in Central Europe with early humans and the first dairy farmers. However, our ability to understand mastitis was limited until the advent and improvement of the light microscope in the 17th century. The earliest scientific report on bovine mastitis came in 1917, when Breed and Brew presented their microscopic method of grading dairies based on the quantity of bacteria in milk (Breed and Brew, 1917; Wollman et al., 2015). Since then, research efforts have evolved from an initial focus on understanding the etiology of IMI to the application of preventative measures, including investigations into genetic predisposition to mastitis and the possibility of breeding cows that are resistant to infection.

\section{A CRITICAL ISSUE FOR THE DAIRY INDUSTRY}

Mastitis is internationally regarded as an economic problem with implications for animal welfare and public health. The mortality rate for clinical mastitis is very low, but farms with mastitis problems suffer substantial economic losses as a result of factors such as decreases in milk production, diagnostic tests, drug treatments, discarded milk, veterinary services, treatment labor, declines in product quality, and culling (Seegers et al., 2003). Considering all of these factors, a recent study estimated the average cost of a case of clinical mastitis to be $\$ 444$, suggesting that annual losses in the United States alone amount to almost $\$ 2$ billion (Rollin et al., 2015; iGEM, 2016). Secondary to lameness, mastitis is the leading antagonist to animal health and welfare, and improving cow recovery and reducing infection severity is considered to be the fastest way to enhance cow welfare with regards to IMI (Hillerton and Berry, 2005). Furthermore, bacterial presence in milk poses a public health problem, because mastitis pathogens have been known to cause human disease, and improper pasteurization techniques (or lack thereof) can result in the contamination of food products (Oliver et al., 2005). Additionally, the often low cure rates and potential antibiotic residues in milk lead to fears of increasing antimicrobial resistance and a call for methods of mastitis control that do not involve antibiotic treatment (Gomes and Henriques, 2016).
A major obstacle for mastitis control lies in the problem of disease detection. A nationwide survey estimated that the prevalence of clinical mastitis was $25 \%$, but with no mandate for participation in monthly milk testing, the occurrence of subclinical mastitis in United States dairy herds cannot be accurately measured (National Animal Health and Monitoring System, 2016). This is known as the "iceberg principle," in which only a small proportion of information is visible while the bulk of the information about a phenomenon is unavailable or undetectable (Figure 1). In the case of mastitis, the problem extends below the tier of subclinical mastitis to the entire population of milking cows, all of whom are susceptible to IMI. In response to this high population-wide risk of developing mastitis, stringent protocols for mastitis management and control have been implemented. Approaches have included reducing exposure to pathogens by prioritizing improvements to cow housing, ensuring milking hygiene, and minimizing teat lesions (Dodd, 1983; Bartlett et al., 1992). Additional emphasis has been given to milking machine effects and examining the resistance of the teat canal itself to bacterial invasion, considering factors such as overmilking, milk flow, vacuum level, liner slips, and pulsation (Thompson et al., 1978; Natzke et al., 1982; Baxter et al., 1992; Lacy-Hulbert and Hillerton, 1995; Wieland et al., 2018). Research has also focused on the potential dispersal of bacteria in the udder by considering factors such as hand-stripping to remove foremilk and the frequency of udder evacuations (Mein et al., 2004; Shoshani et al., 2017). Other external factors, such as cow age, season, and climate have also been examined for their influence on the occurrence of mastitis (Fox et al., 1995; Bates and Dohoo, 2016; Zhang et al., 2016). Although numerous studies have shown that regulation of these factors reduces the incidence of mastitis on farm, they have not addressed the effect of the individual cow on mastitis susceptibility. Mastitis is a multifaceted issue: an estimated $30 \%$ of mastitis problems are attributable each to farm and milking management, $20 \%$ to the milking machine, and $20 \%$ to the cow herself (Mein et al., 2004). In 1994, milk SCC was added to national genetic evaluation systems specifically to address the high prevalence of mastitis in United States dairy herds (Schutz, 1994).

\section{MOLECULAR GENETIC APPROACHES TO UNDERSTANDING MASTITIS}

Substantial progress in genetic improvement for various dairy cattle production traits was made in the pre-genomics era by collecting performance records and pedigree information, making daughter-dam 
comparisons, and developing selection indices (Weigel et al., 2017). The use of molecular genetics in bovine production originated with blood typing for parentage verification to ensure correct pedigree records, but advances in molecular methods allowed the commercial use of marker-based parentage testing by the turn of the 21st century (Stormont, 1967; Dekkers, 2004; Wiggans et al., 2017). The genomics boom allowed research to include the identification of candidate genes and biological pathways underlying mastitis to improve our understanding of the disease and the effective implementation of marker-based selection against mastitis.

Following the successful sequencing of the human genome, the Bovine Genome Project was initiated in 2003 which, together with additional low-depth sequencing of multiple breeds, provided enough information for the development of a SNP assay (Wiggans et al., 2017). Unfortunately, the 15,036 SNPs on the first genotyping panel released in 2005 were poorly distributed across the genome and unable to adequately detect linkage disequilibrium, making it inappropriate for use in QTL mapping and genomic selection (Khatkar et al., 2007; Hayes et al., 2013). In December 2007, the Illumina BovineSNP50 BeadChip (offering 54,001 SNPs; Illumina Inc., San Diego, CA) was released, followed 3 yr later by the high-density Bovine HD chip, which boasted 777,962 SNPs (Matukumalli et al., 2009; Illumina, 2010). Genotype imputation of data from low-density SNP chips has been used to maximize

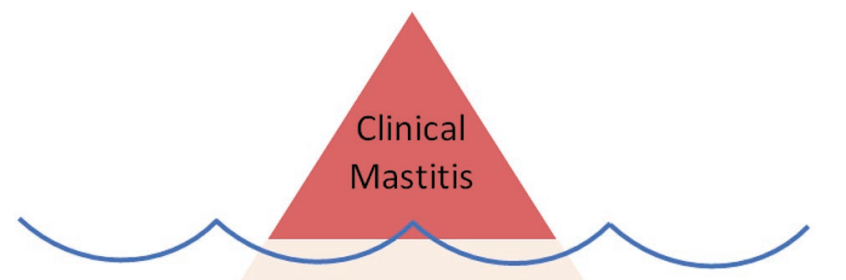

Subclinical Mastitis

\section{Susceptible Cows}

Figure 1. The "iceberg principle" as applied to mastitis. Only a small percentage of mastitis cases are clinically detectable. Beneath those cases, many more cows have subclinical mastitis, and beneath that is an even larger population of susceptible cows (i.e., cows who are at risk of developing mastitis). genome coverage and minimize costs and is based on the principle that any 2 individuals may share genetic information derived from a distant common ancestor. Under this assumption, low-density genotypes may be compared with a large reference population that has no missing data (e.g., whole genome sequences), and their complete genotypes inferred or "imputed" based on the haplotypes (sets of markers inherited together) observed in the reference population (Das et al., 2018).

Prior to the availability of high-density genomic data, complex traits were analyzed primarily via QTL mapping. This approach is based on the concept of linkage disequilibrium which, contrary to Mendel's principle of independent assortment, suggests that alleles at different loci are linked and may be inherited together. This method assumes that markers that are consistently associated with the inheritance of a particular trait must be linked with a QTL that contributes to that trait. Note that QTL mapping is traditionally performed within families or in controlled crosses of contrasting parents for the trait of interest, where only 1 recombination event is recorded in the population, and the $\mathrm{F}_{1}$ generation is assessed for correlation between the inheritance of a particular allele and a quantitative phenotype (Broman, 2001). This presents both computing and financial problems when applied to large dairy cattle populations, considering high genotyping costs, attempts to increase resolution with advanced intercrosses, and the long generation intervals required for genotyping progeny. Enter the GWAS.

Unlike traditional linkage mapping, which assesses whether a disease and an allele show correlated transmission within a pedigree, GWAS associate markers and traits in a freely interbreeding population and do not consider familial inheritance patterns (Lander and Schork, 1994). These GWAS were originally conducted as case-control studies comparing allelic frequencies in affected and unaffected populations; appropriately selecting a control group is a major challenge in contrast to linkage methods, which do not require a control. Although GWAS are high-resolution and less laborintensive, they are sensitive to underlying population structure which can cause spurious associations $(\mathrm{Li}$, 1969; Platt et al., 2010). This is a particular problem in dairy cattle, in which selection for desirable traits has occurred over centuries using both phenotypic and genotypic data, meaning that positive associations must be cautiously interpreted. Observed positive associations may occur because the allele in question is actually causative or if that allele is in linkage disequilibrium with the actual cause, but associations can also occur as an artifact of population structure. In other words, if independent alleles and traits occur in high 
frequency in a certain population, they may be falsely associated with one another. This problem is best ameliorated by conducting GWAS only in large, homogeneous populations and by selecting control groups that are perfectly matched for ancestry (Lander and Schork, 1994). Because that approach is impossible in practice, numerous methods have been implemented to account for bias introduced by underlying population structure, including the selection of internal controls by haplotype relative risk estimation and the inclusion of identity-bystate matrices in GWAS models (Falk and Rubinstein, 1987; Kang et al., 2010).

These molecular approaches provide insight into the genetic background of mastitis and improve our understanding of the biology of the disease, but they may also be practically applied through the inclusion of these markers in genetic selection strategies. Over the last 2 decades, overall genetic improvement for mastitisrelated traits (e.g., SCC, udder, and teat morphology) has been observed in US dairy cattle, likely due to the incorporation of these traits into national genetic evaluations (García-Ruiz et al., 2016).

\section{CURRENT UNDERSTANDING AND APPLICATION OF GENETICS INFLUENCING MASTITIS}

Progress on the investigation of quantitative traits in cattle is documented in the Cattle Quantitative Trait Locus Database (Cattle QTLdb) to facilitate meta-analyses and validation of association data $(\mathrm{Hu}$ et al., 2013). As of the most recent release in August 2019, a total of 2,045 QTL have been associated with the mastitis phenotypes of SCC, SCS, and clinical mastitis. These QTL span all 29 autosomes and the X chromosome, and were generated via a combination of traditional linkage analysis, QTL mapping, and GWAS (Hu et al., 2019, CattleQTLdb, 2019). The complex, polygenic nature of mastitis is reinforced by the significant association of many different regions across the genome.

Subsequent investigation of these associated QTL has implicated many biological pathways in the genetics underlying mastitis, including toll-like receptor signaling, the bovine major histocompatibility complex, and inflammatory mediator expression. Toll-like receptor signaling pathways have been associated with mastitis and are heavily implied in response to multiple types of mastitis pathogens, including Escherichia coli, Staphylococcus aureus, and Streptococcus uberis (Yang et al., 2008; Elmaghraby et al., 2018; Li et al., 2020). In addition to these innate immune response pathways, polymorphisms in the bovine major histocompatibility complex - which is crucial to the initiation of the adaptive immune response - have been heavily associated with mastitis susceptibility (Giphart et al., 1990; Lundén et al., 1990; Aarestrup et al., 1995; Abdel Hameed et al., 2006). Another major finding is that the pathways involved in mastitis response vary by etiology, and many cytokines and inflammatory mediators of mastitis have a specific pathogen-dependent expression profile (Bannerman, 2009). For example, E. coli-induced mastitis is characterized by a rapid acute phase response, whereas $S$. aureus-induced mastitis does not quickly induce an inflammatory response in the udder (Yang et al., 2008; Buitenhuis et al., 2011). These examples illustrate how investigation into the many genetic mechanisms underlying mastitis provides biological insight, which is equally important to genetic improvement by marker-assisted selection.

Many markers associated with these biological pathways have been incorporated into dairy cattle genetic evaluations to build on existing selection strategies in the dairy cattle industry (Weigel et al., 2017). Although individual national genetic evaluation systems are common, the increase in trade of semen, embryos, and livestock led to the formation of Interbull in 1983 to promote the international exchange of information and the most effective genetic evaluation of cattle. For example, Interbull currently employs the multiple across-country evaluation (MACE) method for calculating international genetic evaluations for 7 traits, including udder health. This method incorporates genotype-by-environment interactions that account for animals performing better in certain countries, as well as all available relationship data (within and across populations; Interbull Centre, 2020).

The USDA began collecting cow records in 1895 . Udder and teat type traits were included in genetic evaluations as early as 1978 because of their effect on milking efficiency, as well as their implications for mastitis, and in 1994 SCS was incorporated into national genetic evaluations specifically to address mastitis occurrence in US dairy herds (Van Raden, 2017). In 2009, the first official genomic evaluations in the United States were released, and 4 years after that, responsibility for the administration of national genetic evaluations was transferred to the Council on Dairy Cattle Breeding (Van Raden, 2017). Mastitis resistance has remained a priority for the dairy industry, and in 2017, Zoetis introduced its genomic prediction Wellness Trait Index, which includes mastitis in estimating differences in expected lifetime profit (McNeel et al., 2017; Zoetis, 2017). Interbull led the way with direct selection against mastitis much earlier, but in 2018 clinical mastitis resistance was included in US genetic evaluations (Council on Dairy Cattle Breeding, 2018). 
The accuracy of these evaluations are measured via reliabilities, a measure of the standard error of genomic breeding values. The reliabilities for directly evaluated phenotypes such as protein, fat, and milk yield are quite high (all 90\%) (VanRaden and Cole, 2014). In the case of more complex traits such as mastitis, we observe lower reliabilities for SCS (75\%), but this is still a dramatic improvement from the reliability for SCS using traditional evaluations and no incorporation of genomic information (35.3\%; VanRaden and Cole, 2014). We have seen substantial genetic improvements with regards to mastitis thanks to these selection strategies, with an average rate of mastitis resistance among US Holsteins of 89.8\% (García-Ruiz et al., 2016; Council on Dairy Cattle Breeding, 2018).

\section{CHALLENGES AND LIMITATIONS IN BIOLOGICAL INSIGHT AND APPLICATION}

A major challenge in selecting for mastitis resistance has been the standardization and reporting of mastitis phenotypes. Reports on mastitis heritability, or the degree of variation in mastitis that can be explained by additive genetic differences, were made as early as 1944 and have ranged from 0.1 to 0.88 (Gaunt et al., 1980; Shook and Schutz, 1994; Nash et al., 2000; Vallimont et al., 2009; Ruegg, 2017). The lack of consensus for mastitis heritability estimates is due not only to high variation in management systems and environments, but also to the lack of standardized mastitis diagnosis and reporting, as well as the use of a variety of direct and indicator traits. The formation of Interbull has aided in the standardization of mastitis reporting internationally, and European countries have a significant advantage when it comes to phenotype recording and standardization, given the more extensive involvement of veterinarians and national recording systems. In the United States, this issue was ameliorated by the widespread adoption of DHI testing and milk SCC measures. Although the DHIA was founded in 1905, it still has only $46 \%$ nationwide participation today (Voelker, 1981; DairyOne, 2019).

Another major challenge in mastitis genetic progress attributable to marker-based selection was the realization that most economically important dairy cattle traits such as mastitis are controlled by many genes with small effects (Cole et al., 2009). A genetic correlation between mastitis and milk production traits has been well established, and these mastitis QTL are potentially pleiotropic for milk production traits, such that a major challenge lies in selecting for mastitisresistant cows without sacrificing milk yield, given their unfavorable genetic correlation (Koivula et al.,
2005, Kadri et al., 2015). It is possible that the use of more robust phenotypes may refine genomic regions to mastitis-exclusive QTL. For example, differing genetic patterns have been associated with milk SCS based on lactation stage (Miles and Huson, 2020). Nonpathogenic causes of inflammation (such as lactogenesis and uterine involution during early lactation) could introduce mastitis phenotype bias, and considering alternative SCS traits such as recoverability, standard deviation, and maximum values may refine SCS as a mastitis indicator trait (Bionaz et al., 2007; Graugnard et al., 2012). Furthermore, the large environmental effect on mastitis may minimize improvement by means of genetic selection.

Genotype imputation has proven to be a critical tool that dramatically increases genome coverage. However, in principle it introduces bias toward population averages and limits researcher ability to detect rare variants that do not occur frequently in the reference population (Marchini and Howie, 2010; Calus et al., 2014; Marete et al., 2018). It is possible that additional mastitis-specific QTL will be identified as whole-genome sequencing approaches and the assembly of robust mastitis phenotypes (e.g., microbial sequencing profiles) will become more affordable.

Other challenges with the genetic analysis of complex traits such as mastitis lie in the determination of statistical significance. A GWAS represents a massive multiple testing problem: depending on the genotype density, researchers may be running millions of regressions for genetic variants against a single trait. To mitigate association inflation with false positives, a Bonferroni multiple testing correction may be applied, or the less stringent false discovery rate calculation may be performed, where the researcher sets a significance level accounting for a certain proportion of falsely associated QTL (Benjamini and Hochberg, 1995; Weller et al., 1998). Despite measures to minimize false positives and correct population structure, the only evidence that positive associations are "real" is repeatability in independent populations; thus, GWAS validation is crucial. This presents a challenge in dairy cattle, where the overuse of favorite sires has contributed to high inbreeding and replicated population structure in multiple data sets, suggesting that the most convincing validation is across breeds (Forutan et al., 2018). Significantly associated markers are most compelling when linked with biologically relevant genes, which should be further validated through targeted sequencing and functional analyses at the transcriptional and translational levels. Molecular investigation into biological pathways may mitigate the inflation of false positives by highlighting variants with causative effects. 


\section{OPPORTUNITIES AND FUTURE DIRECTIONS}

Current research has identified a large number of mastitis QTL spanning the entire genome, and even larger numbers of candidate genes in these regions; this may be explained by the recently proposed "omnigenic model," which posits that the genetic architecture of complex traits is produced by a massive regulatory network of genes, each with very small effect (Boyle et al., 2017). The "core" genes, whose annotated function are obviously related to mastitis, have a minimal effect compared with the "peripheral" genes, which have non-disease-specific roles in regulating disease risk and exist in a much greater number. The classical theory behind genetic association studies assumes that identifying core genes will improve our understanding of the biology underlying disease; this is certainly true for monogenic diseases, but it may not hold for complex traits such as mastitis. Part of this problem lies in the incomplete annotation of genes, core or otherwise. A good example of this problem is the limited functional annotation of individual synaptic genes, which does not reflect what is known about the larger picture of synaptic biology (Lips et al., 2012; Wray et al., 2018). A major tenet of the omnigenic model is that of universal pleiotropy, a hypothesis which suggests that almost all genes expressed in a cell type may have weak effects on disease expression, and that together these peripheral genes account for the majority of the heritability of the trait (Boyle et al., 2017). The implications are that we will need a clearer understanding of cellular networks to understand the genetic drivers of mastitis, and this may enhance genetic progress in selection for mastitis resistance by providing biological insight and clarifying the downstream effects of marker variants.

The importance of pathogen diagnosis and targeted treatment has long been recognized, and on-farm culture systems have been used despite varied sensitivity and specificity reports (McCarron et al., 2009; Ganda et al., 2016; Ferreira et al., 2018). Although the incorporation of microbial sequencing techniques is not yet practical on farm, it would allow for the most precise phenotyping of mastitis, and dissecting mastitis by specific etiology may clarify the genetic mechanisms at play given the pathogen-specific immunological responses often observed (Yang et al., 2008; Bannerman, 2009; Buitenhuis et al., 2011). Advances in next-generation sequencing technologies provide the opportunity to investigate pathogen-specific mastitis resistance.

\section{CONCLUSIONS}

Mastitis is of significant concern to the global dairy industry, and as a result multiple initiatives and orga- nizations have been formed to encourage standardized reporting and genetic evaluation of dairy cattle for mastitis resistance. One of the challenges in selecting for mastitis-resistant cows lies in its highly polygenic and potentially pleiotropic nature, as well as its negative correlation with desirable production traits such as milk yield. Various molecular genetic approaches have associated over 2,000 QTL with direct mastitis measures, as well as mastitis indicator traits, spanning the entire bovine genome. Advances in next-generation sequencing technologies provide an opportunity to clarify the genetic mechanisms underlying mastitis by refining mastitis phenotyping with microbial sequencing and increasing the power to detect rare variants through whole bovine genome sequencing. A major obstacle in understanding the genetic background of mastitis lies in our incomplete understanding of cellular networks and the potential importance of highly abundant peripheral genes with non-disease-specific roles in regulating disease risk. Nevertheless, substantial progress has been made thanks to national and international efforts in genetic evaluation.

\section{ACKNOWLEDGMENTS}

This graduate student literature review came out of a larger research investigation funded by the US Department of Agriculture National Institute of Food and Agriculture (USDA/NIFA, Washington, DC) Federal Formula Funds Hatch Project NYC-127898. The authors have not stated any conflicts of interest.

\section{REFERENCES}

Aarestrup, F. M., N. E. Jensen, and H. Østergård. 1995. Analysis of associations between major histocompatibility complex (BoLA) class I haplotypes and subclinical mastitis of dairy cows. J. Dairy Sci. 78:1684-1692. https://doi.org/10.3168/jds.S0022-0302(95)76793 -5 .

Abdel Hameed, K., G. Sender, and M. Mayntz. 2006. Major histocompatibility complex polymorphism and mastitis resistence-A review. Anim. Sci. Pap. Rep. 24:11-25.

Bannerman, D. D. 2009. Pathogen-dependent induction of cytokines and other soluble inflammatory mediators during intramammary infection of dairy cows. J. Anim. Sci. 87(13 Suppl):10-25. https:// doi.org/10.2527/jas.2008-1187.

Bartlett, P. C., G. Y. Miller, S. E. Lance, D. D. Hancock, and L. E. Heider. 1992. Managerial risk factors of intramammary infection with Streptococcus agalactiae in dairy herds in Ohio. Am. J. Vet. Res. 53:1715-1721.

Bates, A. J., and I. Dohoo. 2016. Risk factors for peri-parturient farmer diagnosed mastitis in New Zealand dairy herds: Findings from a retrospective cohort study. Prev. Vet. Med. 127:70-76. https://doi .org/10.1016/j.prevetmed.2016.03.009.

Baxter, J. D., G. W. Rogers, S. B. Spencer, and R. J. Eberhart. 1992. The effect of milking machine liner slip on new intramammary infections. J. Dairy Sci. 75:1015-1018. https://doi.org/10.3168/jds .S0022-0302(92)77844-8.

Benjamini, Y., and Y. Hochberg. 1995. Controlling the false discovery rate: A practical and powerful approach to multiple testing. J. R. 
Stat. Soc. B 57:289-300. https://doi.org/10.1111/j.2517-6161.1995 tb02031.x.

Bionaz, M., E. Trevisi, L. Calamari, F. Librandi, A. Ferrari, and G. Bertoni. 2007. Plasma paraoxonase, health, inflammatory conditions, and liver function in transition dairy cows. J. Dairy Sci. 90:1740-1750. https://doi.org/10.3168/jds.2006-445.

Bollongino, R., J. Burger, A. Powell, M. Mashkour, J.-D. Vigne, and M. G. Thomas. 2012. Modern taurine cattle descended from small number of Near-Eastern founders. Mol. Biol. Evol. 29:2101-2104. https://doi.org/10.1093/molbev/mss092.

Boyle, E. A., Y. I. Li, and J. K. Pritchard. 2017. An expanded view of complex traits: From polygenic to omnigenic. Cell 169:1177-1186. https://doi.org/10.1016/j.cell.2017.05.038.

Breed, R. S., and J. D. Brew. 1917. The control of public milk supplies by the use of the microscopic method. J. Dairy Sci. 1:259-271. https://doi.org/10.3168/jds.S0022-0302(17)94379-6.

Broman, K. W. 2001. Review of statistical methods for QTL mapping in experimental crosses. Lab. Anim. (NY) 30:44-52.

Buitenhuis, B., C. M. Røntved, S. M. Edwards, K. L. Ingvartsen, and P. Sørensen. 2011. In depth analysis of genes and pathways of the mammary gland involved in the pathogenesis of bovine Escherichia coli-mastitis. BMC Genomics 12:130. https://doi.org/10.1186/ 1471-2164-12-130.

Calus, M. P., A. C. Bouwman, J. M. Hickey, R. F. Veerkamp, and H. A. Mulder. 2014. Evaluation of measures of correctness of genotype imputation in the context of genomic prediction: A review of livestock applications. Animal 8:1743-1753. https://doi.org/10 $.1017 / \mathrm{S} 1751731114001803$.

CattleQTLdb. 2019. QTL/associations for trait type mastitis in the cattle genome. Accessed November 2019. https://www .animalgenome.org/cgi-bin/QTLdb/BT/traitmap?trait_ID=1439 \&traitnm $=$ Mastitis

Cole, J. B., P. M. VanRaden, J. R. O'Connell, C. P. Van Tassell, T. S. Sonstegard, R. D. Schnabel, J. F. Taylor, and G. R. Wiggans. 2009. Distribution and location of genetic effects for dairy traits. J. Dairy Sci. 92:2931-2946. https://doi.org/10.3168/jds.2008-1762.

Council on Dairy Cattle Breeding. 2018. Resistance to mastitis (MAST) trait reference sheet. Accessed Nov. 2019. https://www .uscdcb.com/wp-content/uploads/2018/03/CDCB-Reference -Sheet-MAST-03_2018.pdf.

DairyOne. 2019. Dairy Herd Improvement Association: What is it? Who is it? Vol. 2019. Accessed Nov. 2019. https://dairyone.com/ dairy-herd-improvement-association-what-is-it-who-is-it/.

Das, S., G. R. Abecasis, and B. L. Browning. 2018. Genotype imputation from large reference panels. Annu. Rev. Genomics Hum. Genet. 19:73-96. https://doi.org/10.1146/annurev-genom-083117 -021602 .

Dekkers, J. C. 2004. Commercial application of marker- and geneassisted selection in livestock: Strategies and lessons. J. Anim. Sci. 82(E-Suppl):E313-E328. https://doi.org/10.2527/2004.8213 _supplE313x.

Dodd, F. H. 1983. Mastitis - Progress on control. J. Dairy Sci. 66:17731780. https://doi.org/10.3168/jds.S0022-0302(83)82005-0.

Elmaghraby, M. M., A. F. El-Nahas, M. M. Fathala, F. M. Sahwan, and M. A. Tag El-Dien. 2018. Association of toll-like receptors 2 and 6 polymorphism with clinical mastitis and production traits in Holstein cattle. Iran J. Vet. Res. 19:202-207.

Falk, C. T., and P. Rubinstein. 1987. Haplotype relative risks: An easy reliable way to construct a proper control sample for risk calculations. Ann. Hum. Genet. 51:227-233. https://doi.org/10.1111/j .1469-1809.1987.tb00875.x.

Ferreira, J. C., M. S. Gomes, E. C. R. Bonsaglia, I. F. Canisso, E. F. Garrett, J. L. Stewart, Z. Zhou, and F. S. Lima. 2018. Comparative analysis of four commercial on-farm culture methods to identify bacteria associated with clinical mastitis in dairy cattle. PLoS One 13:e0194211. https://doi.org/10.1371/journal.pone.0194211.

Flajnik, M. F., and M. Kasahara. 2010. Origin and evolution of the adaptive immune system: Genetic events and selective pressures. Nat. Rev. Genet. 11:47-59. https://doi.org/10.1038/nrg2703.

Forutan, M., S. Ansari Mahyari, C. Baes, N. Melzer, F. S. Schenkel, and M. Sargolzaei. 2018. Inbreeding and runs of homozygosity before and after genomic selection in North American Holstein cattle. BMC Genomics 19:98. https://doi.org/10.1186/s12864-018 $-4453-z$.

Fox, L. K., S. T. Chester, J. W. Hallberg, S. C. Nickerson, J. W. Pankey, and L. D. Weaver. 1995. Survey of intramammary infections in dairy heifers at breeding age and first parturition. J. Dairy Sci. 78:1619-1628. https://doi.org/10.3168/jds.S0022-0302(95)76786 -8 .

Ganda, E. K., R. S. Bisinotto, D. H. Decter, and R. C. Bicalho. 2016 Evaluation of an on-farm culture system (Accumast) for fast identification of milk pathogens associated with clinical mastitis in dairy cows. PLoS One 11:e0155314. https://doi.org/10.1371/ journal.pone.0155314.

García-Ruiz, A., J. B. Cole, P. M. VanRaden, G. R. Wiggans, F. J. Ruiz-López, and C. P. Van Tassell. 2016. Changes in genetic selection differentials and generation intervals in US Holstein dairy cattle as a result of genomic selection. Proc. Natl. Acad. Sci. USA 113:E3995-E4004. https://doi.org/10.1073/pnas.1519061113.

Gaunt, S. N., N. Raffio, E. T. Kingsbury, R. A. Damon Jr., W. H. Johnson, and B. A. Mitchell. 1980. Variation of lactoferrin and mastitis and their heritabilities. J. Dairy Sci. 63:1874-1880. https: //doi.org/10.3168/jds.S0022-0302(80)83154-7.

Giphart, M. J., M. A. Groenen, and J. J. van der Poel. 1990. Homologies between the major histocompatibility complex of man and cattle: Consequences for disease resistance and susceptibility. Vet. Q. 12:202-211. https://doi.org/10.1080/01652176.1990.9694267.

Gomes, F., and M. Henriques. 2016. Control of bovine mastitis: Old and recent therapeutic approaches. Curr. Microbiol. 72:377-382. https://doi.org/10.1007/s00284-015-0958-8.

Graugnard, D. E., M. Bionaz, E. Trevisi, K. M. Moyes, J. L. SalakJohnson, R. L. Wallace, J. K. Drackley, G. Bertoni, and J. J. Loor. 2012. Blood immunometabolic indices and polymorphonuclear neutrophil function in peripartum dairy cows are altered by level of dietary energy prepartum. J. Dairy Sci. 95:1749-1758. https:// doi.org/10.3168/jds.2011-4579.

Hayes, B. J., H. A. Lewin, and M. E. Goddard. 2013. The future of livestock breeding: Genomic selection for efficiency, reduced emissions intensity, and adaptation. Trends Genet. 29:206-214. https:/ /doi.org/10.1016/j.tig.2012.11.009.

Hillerton, J. E., and E. A. Berry. 2005. Treating mastitis in the cowA tradition or an archaism. J. Appl. Microbiol. 98:1250-1255. https://doi.org/10.1111/j.1365-2672.2005.02649.x.

Hu, Z.-L., C. A. Park, and J. M. Reecy. 2019. Building a livestock genetic and genomic information knowledgebase through integrative developments of Animal QTLdb and CorrDB. Nucleic Acids Res. 47(D1):D701-D710. https://doi.org/10.1093/nar/gky1084.

Hu, Z.-L., C. A. Park, X.-L. Wu, and J. M. Reecy. 2013. Animal QTLdb: An improved database tool for livestock animal QTL/association data dissemination in the post-genome era. Nucleic Acids Res. 41(D1):D871-D879. https://doi.org/10.1093/nar/gks1150.

iGEM. 2016. Market analysis: Bovine mastitis. Cornell University. Accessed Nov. 2019. http://2016.igem.org/wiki/images/2/21/ T-Cornell_NY-MarketAnalysis.pdf.

Illumina. 2010. Bovine HD Genotyping BeadChip Data Sheet. Vol. 2019, Illumina, San Diego, CA.

Interbull Centre. 2020. Interbull Code of Practice. Accessed Jul. 1, 2020. https://interbull.org/ib/codeofpractice.

Itan, Y., A. Powell, M. A. Beaumont, J. Burger, and M. G. Thomas. 2009. The origins of lactase persistence in Europe. PLOS Comput. Biol. 5:e1000491. https://doi.org/10.1371/journal.pcbi.1000491.

Kadri, N. K., B. Guldbrandtsen, M. S. Lund, and G. Sahana. 2015. Genetic dissection of milk yield traits and mastitis resistance quantitative trait loci on chromosome 20 in dairy cattle. J. Dairy Sci. 98:9015-9025. https://doi.org/10.3168/jds.2015-9599.

Kang, H. M., J. H. Sul, S. K. Service, N. A. Zaitlen, S.-y. Kong, N. B. Freimer, C. Sabatti, and E. Eskin. 2010. Variance component model to account for sample structure in genome-wide association studies. Nat. Genet. 42:348-354. https://doi.org/10.1038/ng.548.

Khatkar, M. S., K. R. Zenger, M. Hobbs, R. J. Hawken, J. A. L. Cavanagh, W. Barris, A. E. McClintock, S. McClintock, P. C. Thomson, B. Tier, F. W. Nicholas, and H. W. Raadsma. 2007. 
A primary assembly of a bovine haplotype block map based on a 15,036-single-nucleotide polymorphism panel genotyped in Holstein-Friesian cattle. Genetics 176:763-772. https://doi.org/10 .1534 /genetics.106.069369.

Koivula, M., E. A. Mäntysaari, E. Negussie, and T. Serenius. 2005. Genetic and phenotypic relationships among milk yield and somatic cell count before and after clinical mastitis. J. Dairy Sci. 88:827-833. https://doi.org/10.3168/jds.S0022-0302(05)72747-8.

Lacy-Hulbert, S. J., and J. E. Hillerton. 1995. Physical characteristics of the bovine teat canal and their influence on susceptibility to streptococcal infection. J. Dairy Res. 62:395-404. https://doi.org/ 10.1017/S0022029900031101.

Lander, E. S., and N. J. Schork. 1994. Genetic dissection of complex traits. Science 265:2037-2048. https://doi.org/10.1126/science .8091226

Li, B., Z. Wan, Z. Wang, J. Zuo, Y. Xu, X. Han, V. Phouthapane, and J. Miao. 2020. TLR2 signaling pathway combats Streptococcus uberis infection by inducing mitochondrial reactive oxygen species production. Cells 9:494. https://doi.org/10.3390/cells9020494.

Li, C. C. 1969. Population subdivision with respect to multiple alleles. Ann. Hum. Genet. 33:23-29. https://doi.org/10.1111/j.1469-1809 1969.tb01625.x.

Lips, E. S., L. N. Cornelisse, R. F. Toonen, J. L. Min, C. M. Hultman, P. A. Holmans, M. C. O'Donovan, S. M. Purcell, A. B. Smit, M. Verhage, P. F. Sullivan, P. M. Visscher, and D. Posthuma. 2012. Functional gene group analysis identifies synaptic gene groups as risk factor for schizophrenia. Mol. Psychiatry 17:996-1006. https:/ /doi.org/10.1038/mp.2011.117.

Lundén, A., S. Sigurdardóttir, I. Edfors-Lilja, B. Danell, J. Rendel, and L. Andersson. 1990. The relationship between bovine major histocompatibility complex class II polymorphism and disease studied by use of bull breeding values. Anim. Genet. 21:221-232. https://doi.org/10.1111/j.1365-2052.1990.tb03232.x.

Marchini, J., and B. Howie. 2010. Genotype imputation for genomewide association studies. Nat. Rev. Genet. 11:499-511. https://doi .org/10.1038/nrg2796.

Marete, A., M. S. Lund, D. Boichard, and Y. Ramayo-Caldas. 2018. A system-based analysis of the genetic determinism of udder conformation and health phenotypes across three French dairy cattle breeds. PLoS One 13:e0199931. https://doi.org/10.1371/journal pone.0199931.

Matukumalli, L. K., C. T. Lawley, R. D. Schnabel, J. F. Taylor, M. F. Allan, M. P. Heaton, J. O'Connell, S. S. Moore, T. P. L. Smith, T. S. Sonstegard, and C. P. Van Tassell. 2009. Development and characterization of a high density SNP genotyping assay for cattle. PLoS One 4:e5350. https://doi.org/10.1371/journal.pone.0005350.

McCarron, J. L., G. P. Keefe, S. L. McKenna, I. R. Dohoo, and D. E. Poole. 2009. Evaluation of the University of Minnesota Triplate and 3M Petrifilm for the isolation of Staphylococcus aureus and Streptococcus species from clinically mastitic milk samples. J. Dairy Sci. 92:5326-5333. https://doi.org/10.3168/jds.2009-2333.

McNeel, A. K., B. C. Reiter, D. Weigel, J. Osterstock, and F. A. Di Croce. 2017. Validation of genomic predictions for wellness traits in US Holstein cows. J. Dairy Sci. 100:9115-9124. https://doi.org/ 10.3168/jds.2016-12323.

Mein, G., D. Reinemann, N. Schuring, and I. Ohnstad. 2004. Milking machines and mastitis risk: A storm in a teatcup. Pages 34-36 in Proc. Natl. Mastitis Counc. Ann. Mtg. Natl. Mastitis Counc., Charlotte, NC.

Miles, A. M., and H. J. Huson. 2020. Time- and population-dependent genetic patterns underlie bovine milk somatic cell count. J. Dairy Sci. 103:8292-8304. https://doi.org/10.3168/jds.2020-18322.

Muthamilarasan, M., and M. Prasad. 2013. Plant innate immunity: An updated insight into defense mechanism. J. Biosci. 38:433-449. https://doi.org/10.1007/s12038-013-9302-2.

Nash, D. L., G. W. Rogers, J. B. Cooper, G. L. Hargrove, J. F. Keown, and L. B. Hansen. 2000. Heritability of clinical mastitis incidence and relationships with sire transmitting abilities for somatic cell score, udder type traits, productive life, and protein yield. J. Dairy Sci. 83:2350-2360. https://doi.org/10.3168/jds.S0022 -0302(00)75123-X.
National Animal Health and Monitoring System. 2016. Dairy 2014: Milk Quality, Milking Procedures, and Mastitis on U.S. Dairies. United States Department of Agriculture, Fort Collins, CO.

Natzke, R. P., R. W. Everett, and D. R. Bray. 1982. Effect of overmilking on udder health. J. Dairy Sci. 65:117-125. https://doi.org/10 $.3168 /$ jds.S0022-0302(82)82160-7.

Novacek, M. J. 1997. Mammalian evolution: An early record bristling with evidence. Curr. Biol. 7:R489-R491. https://doi.org/10.1016/ S0960-9822(06)00245-4.

Oliver, S. P., B. Jayarao, and R. Almeida. 2005. Foodborne pathogens in milk and the dairy farm environment: Food safety and public health implications. Foodborne Pathog. Dis. 2:115-129. https:// doi.org/10.1089/fpd.2005.2.115

Platt, A., B. J. Vilhjálmsson, and M. Nordborg. 2010. Conditions under which genome-wide association studies will be positively misleading. Genetics 186:1045-1052. https://doi.org/10.1534/genetics .110 .121665

Rollin, E., K. C. Dhuyvetter, and M. W. Overton. 2015. The cost of clinical mastitis in the first 30 days of lactation: An economic modeling tool. Prev. Vet. Med. 122:257-264. https://doi.org/10.1016/j .prevetmed.2015.11.006.

Ruegg, P. L. 2017. A 100-year review: Mastitis detection, management, and prevention. J. Dairy Sci. 100:10381-10397. https://doi .org/10.3168/jds.2017-13023.

Schutz, M. M. 1994. Genetic evaluation of somatic cell scores for United States dairy cattle. J. Dairy Sci. 77:2113-2129. https://doi.org/ 10.3168/jds.S0022-0302(94)77154-X.

Seegers, H., C. Fourichon, and F. Beaudeau. 2003. Production effects related to mastitis and mastitis economics in dairy cattle herds. Vet. Res. 34:475-491. https://doi.org/10.1051/vetres:2003027.

Shook, G. E., and M. M. Schutz. 1994. Selection on somatic cell score to improve resistance to mastitis in the United States. J. Dairy Sci. 77:648-658. https://doi.org/10.3168/jds.S0022-0302(94)76995-2.

Shoshani, E., M. Cohen, and J. J. Doekes. 2017. Short- and longterm effects of high milking frequency during the first 21 days of lactation on production and reproductive performance in high-lactating cows. Animal 11:91-100. https://doi.org/10.1017/ S1751731116001324.

Stormont, C. 1967. Contribution of blood typing to dairy science progress. J. Dairy Sci. 50:253-260. https://doi.org/10.3168/jds.S0022 -0302(67)87401-0.

Thompson, P. D., W. D. Schultze, J. N. Sauls, and S. C. Arapis. 1978. Mastitis infection from abrupt loss of milking vacuum. J. Dairy Sci. 61:344-351. https://doi.org/10.3168/jds.S0022-0302(78)83604 -2 .

Vallimont, J. E., C. D. Dechow, C. G. Sattler, and J. S. Clay. 2009. Heritability estimates associated with alternative definitions of mastitis and correlations with somatic cell score and yield. J. Dairy Sci. 92:3402-3410. https://doi.org/10.3168/jds.2008-1229.

VanRaden, P. M. 2017. History of USDA dairy evaluations. Accessed May 6, 2020. https://queries.uscdcb.com/aipl/history/hist_eval .htm.

VanRaden, P. M., and J. B. Cole. 2014. Net Merit as a Measure of Lifetime Profit: 2014 Revision. AIP Research Report NM\$5 (1014). Vol. 2019, Animal Genomics and Improvement Laboratory, Agricultural Research Service, USDA, Beltsville, MD.

Voelker, D. E. 1981. Dairy Herd Improvement Associations. J. Dairy Sci. 64:1269-1277. https://doi.org/10.3168/jds.S0022 -0302(81)82700-2.

Weigel, K. A., P. M. VanRaden, H. D. Norman, and H. Grosu. 2017. A 100-year review: Methods and impact of genetic selection in dairy cattle-From daughter-dam comparisons to deep learning algorithms. J. Dairy Sci. 100:10234-10250. https://doi.org/10.3168/ jds.2017-12954.

Weller, J. I., J. Z. Song, D. W. Heyen, H. A. Lewin, and M. Ron. 1998. A new approach to the problem of multiple comparisons in the genetic dissection of complex traits. Genetics 150:1699-1706.

Wieland, M., D. V. Nydam, N. Alveby, P. Wood, and P. D. Virkler 2018. Short communication: Teat-end shape and udder-level milking characteristics and their associations with machine milking- 
induced changes in teat tissue condition. J. Dairy Sci. 101:1144711454. https://doi.org/10.3168/jds.2018-15057.

Wiggans, G. R., J. B. Cole, S. M. Hubbard, and T. S. Sonstegard. 2017. Genomic selection in dairy cattle: The USDA experience. Annu. Rev. Anim. Biosci. 5:309-327. https://doi.org/10.1146/ annurev-animal-021815-111422.

Wollman, A. J. M., R. Nudd, E. G. Hedlund, and M. C. Leake. 2015. From Animaculum to single molecules: 300 years of the light microscope. Open Biol. 5:150019. https://doi.org/10.1098/rsob.150019.

Wray, N. R., C. Wijmenga, P. F. Sullivan, J. Yang, and P. M. Visscher. 2018. Common disease is more complex than implied by the core gene omnigenic model. Cell 173:1573-1580. https://doi.org/ 10.1016/j.cell.2018.05.051.

Yang, W., H. Zerbe, W. Petzl, R. M. Brunner, J. Günther, C. Draing, S. von Aulock, H.-J. Schuberth, and H.-M. Seyfert. 2008. Bovine TLR2 and TLR4 properly transduce signals from Staphylococcus

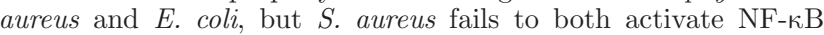

in mammary epithelial cells and to quickly induce TNF $\alpha$ and interleukin-8 (CXCL8) expression in the udder. Mol. Immunol. 45:1385-1397. https://doi.org/10.1016/j.molimm.2007.09.004.

Zhang, Z., X. P. Li, F. Yang, J. Y. Luo, X. R. Wang, L. H. Liu, and H. S. Li. 2016. Influences of season, parity, lactation, udder area, milk yield, and clinical symptoms on intramammary infection in dairy cows. J. Dairy Sci. 99:6484-6493. https://doi.org/10.3168/ jds.2016-10932.

Zoetis. 2017. Build a healthier herd through genetics. Accessed May 6 2020. https://www.zoetisus.com/animal-genetics/dairy/clarifide/ clarifide-plus.aspx

\section{ORCIDS}

Asha M. Miles (ํ) https://orcid.org/0000-0003-2175-7910

Heather J. Huson @ https://orcid.org/0000-0001-8299-0447 